Brit. f. industr. Med., 1968, 25, 75.

\title{
Miscellanea
}

\section{Experimental Studies on Skin Hazard with Cycloocta-1,5-diene and Cyclododeca-I,5,9-triene}

\author{
V. K. H. BROWN and C. G. HUNTER \\ From 'Shell' Research Ltd., Tunstall Laboratory, Sittingbourne, Kent
}

The two oligomers, cycloocta-I,5-diene (COD) and cyclododeca-1,5,9-triene (CDT), are very reactive chemicals and have applications as intermediates in the plastics industry, in the manufacture of synthetic lubricants, and in numerous other industrial and laboratory reactions.

No published information has been found on the toxicity of these chemicals, and the experimental studies reported here were designed to give guidance on the dermal aspect of safe handling.

\section{Experimental}

The samples of COD and CDT were obtained from Shell Chemicals U.K. Company Ltd. The COD sample contained $98 \% \mathrm{w} / \mathrm{w}$ of the cis, cis-isomer with $0.02 \% \mathrm{w} / \mathrm{w}$ 2,6-diterbutyl-4-methylphenol to inhibit the formation of peroxides. The CDT sample contained at least $90 \% \mathrm{w} / \mathrm{w}$ of the cis, trans, trans-isomer with $0.1 \%$ of the same preservative. The physical properties of these compounds are shown in Table $I$ and their structures in Figures $I$ and 2.

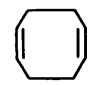

FIG. I

Cycloocto-1.5-diene (COD)

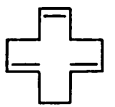

FIG. 2

Cyclododeco-I. 5,9-triene (CDT)

Dermal toxicity was assessed in guinea-pigs, hairless mice, and rabbits by means of tests for the determination of skin irritation and sensitization that have been reported elsewhere (Hunter, Brown, and Ferrigan, I966; Brown, Ferrigan, and Stevenson, 1967; Brown,

Received for publication April 8, 1967.
1967). Tests for the determination of eye irritancy were made on rabbits (United States Federal Register, 1964; U.S. Department of Health, Education and Welfare, I964).

\section{Results}

Skin Irritation Studies In the covered test in rabbits, the irritation caused by both materials was very severe. Epidermal sloughing was particularly apparent after the application of COD. The use of sulphan blue showed the skin to be grossly injured. Histopathological examination of skin taken from the rabbits post mortem revealed necrosis of the epidermis and ulceration and marked inflammation of the dermis with COD, and following CDT application there were acanthosis and a proliferative epidermal reaction.

COD, in the uncovered application tests in rabbits, guinea-pigs, and 'hairless' mice, produced an immediate erythematous reaction after only one application. A severe acute contact dermatitis followed with epidermal sloughing. With the same tests, CDT was highly irritant and produced a very

\section{TABLE I}

Some Physical Properties of Cycloocta-I,5-Diene and CycloDODECA-I, 5,9-TRIENE

\begin{tabular}{|c|c|c|}
\hline & $\begin{array}{l}\text { Cycloocta-1,5- } \\
\text { diene }\end{array}$ & $\begin{array}{l}\text { Cyclododeca-1,5,9- } \\
\text { triene }\end{array}$ \\
\hline $\begin{array}{l}\text { Molecular weight } \\
\text { Boiling point } \\
\quad(760 \mathrm{~mm} . \mathrm{Hg})\left({ }^{\circ} \mathrm{C} .\right)\end{array}$ & $\begin{array}{l}108 \cdot 2 \\
150 \cdot 9\end{array}$ & $162 \cdot 3$ \\
\hline $\begin{array}{l}\text { Boiling point } \\
\text { (I I } \mathrm{mm} . \mathrm{Hg})\left({ }^{\circ} \mathrm{C} .\right)\end{array}$ & 一 & $100 \cdot \infty$ \\
\hline Freezing point $\left({ }^{\circ} \mathrm{C}.\right)$ & $-69 \cdot 5$ & $-18 \cdot 00$ \\
\hline $\begin{array}{l}\text { Refractive index } \\
\mathbf{N}_{\mathbf{D}^{20}}\end{array}$ & I. 4905 & $\mathrm{I} \cdot 5072$ \\
\hline $\begin{array}{l}\text { Density }\left(20^{\circ} \mathrm{C} .\right) \\
(\mathrm{g} . / \mathrm{cc} .)\end{array}$ & 0.8833 & 0.8906 \\
\hline
\end{tabular}


severe contact dermatitis in all species. Ulceration was observed in the skin of one 'hairless' mouse on histopathological examination. With both compounds, hair growth was suppressed around the shorn sites of application in the rabbits and guinea-pigs.

Because of the severity and nature of the reaction, a group of guinea-pigs was treated as above but not killed until three weeks after the last application of test material. Histological examination of the skins from these animals showed that epidermal thickening and considerable acanthosis were still present.

Skin Sensitization Studies Both COD and CDT were found to be potent skin sensitizers in the two tests performed on each compound (Table II).

TABLE II

Sensitization Reactions ObServed in Guinea-Pigs

\begin{tabular}{|c|c|c|c|c|c|}
\hline \multirow{3}{*}{\multicolumn{2}{|c|}{$\begin{array}{c}\text { Material under Test } \\
\text { as } 0 \cdot 1 \% \text { w/v } \\
\text { Solution in Light } \\
\text { Liquid Paraffin }\end{array}$}} & \multicolumn{4}{|c|}{$\begin{array}{l}\text { No. of Guinea-pigs showing } \\
\text { Positive Sensitive Reaction }\end{array}$} \\
\hline & & \multicolumn{2}{|c|}{ Topical Test } & \multicolumn{2}{|c|}{ Intradermal Test } \\
\hline & & 24 hours & 48 hours & 24 hours & 48 hours \\
\hline $\begin{array}{l}\text { COD } \\
\text { CDT }\end{array}$ & $\begin{array}{l}\cdots \\
\cdots\end{array}$ & $\begin{array}{l}10 / 10 \\
10 / 10\end{array}$ & $\begin{array}{l}10 / 10 \\
10 / 10\end{array}$ & $\begin{array}{r}9 / 10 \\
10 / 10\end{array}$ & $\begin{array}{r}9 / 10 \\
10 / 10\end{array}$ \\
\hline
\end{tabular}

Eye Tests in Rabbits Both oligomers were immediately irritant to the eyes but produced only a mild conjunctivitis which faded within 48 hours. The main effect was associated with the eyelids, which became red and swollen and exuded a purulent discharge. The blepharitis caused by
COD took a few days to heal; blepharitis was still apparent one week after the application of CDT.

\section{Discussion and Conclusions}

COD and CDT were shown to be capable of causing severe contact dermatitis, and even trace amounts produced a sensitization reaction. This sensitization reaction to cyclic aliphatic compounds is not unprecedented, as cyclopentadiene was shown to give positive sensitization reactions in man (Malten and Zielhuis, 1964) although only a very faint sensitization reaction was observed in guineapigs with cycloheptatriene (Brown et al., 1967).

It is unlikely that accidental splashing of these two oligomers into the eye will cause permanent damage but pain and discomfort will be apparent. The eyelids in particular may be painfully involved. Nevertheless, immediate first aid is essential.

Strict precautions should be taken to avoid skin contact with either COD or CDT.

\section{REFERENCES}

Brown, V. K. H. (1967). Use of hypotrichotic mammals in experimental skin toxicology. Dermatology Digest, 6, 17-20.

—, Ferrigan, L. W., and Stevenson, D. E. (1967). The acute toxicity and skin irritant properties of tropilidene (cyclohepta-1,3,5-triene). Ann. occup. Hyg., 10, 123I26.

Hunter, C. G., Brown, V. K. H., and Ferrigan, L. W. (1966). Experimental studies on skin hazard with 'Versatic' 9-II acid and its monoglycidyl and vinyl esters. Brit. f. industr. Med., 23, 137-14I.

Malten, K. E., and Zielhuis, R. L. (1964). Industrial Toxicology and Dermatology in the Production and Processing of Plastics. Elsevier, Amsterdam and London.

U.S. Department of Health, Education and Welfare (Food and Drug Administration) (1964). Illustrated Guide for Grading Eye Irritation by Hazardous Substances.

United States Federal Register. (1964). Hazardous Substances, 29 F. R. 13009. 